\title{
China Talks Climate: A Frame Analysis of Discourses on Climate Change and the Environment in the PRC
}

\author{
Prudence Willats
}

\begin{abstract}
In 2007, China overtook the US to become the largest emitter of CO2 into the Earth's atmosphere. China's vital role in global efforts to combat climate change creates a pressing challenge to explore the unique characteristics of Chinese environmental values and policy processes, and to identify the frames that are employed to understand climate change and related environmental issues domestically. This paper investigates a) how the political context, as well as differing political agendas and policy goals within which actors operate, affects and sometimes constrains the frames they generally employ; and b) the specific frames used to understand and discuss climate change by interview subjects and in written documents. It finds that different frames are employed by those supporting the current regime and its attendant official discourses on climate change and the environment (mainly government officials) and those challenging or in opposition to such dominant framings (particularly $N G O s$ ).
\end{abstract}

Keywords: China, environment, development, climate change, frame analysis Climate Change and the Environment in the PRC." In Vienna Journal of East Asian Studies, Volume 8, eds. Rudiger Frank, Ina Hein, Lukas Pokorny, and Agnes Schick-Chen. Vienna: Praesens Verlag, 2016, pp. 193-226. 


\section{China Talks Climate}

Global climate change has a profound impact on the existence and development of mankind, and is a major challenge facing all countries. At stake in the fight against climate change are the common interests of the entire world.

(Hú Jintāo, President of the People's Republic of China, speaking at the Opening Plenary Session of the United Nations Summit on Climate Change, New York, 22 September 2009)

In 2007, China overtook the United States (US) to become the largest emitter of $\mathrm{CO} 2$ into the Earth's atmosphere. This fact alone makes China a key player in global efforts to combat climate change. The complex set of interlinking social, political, and economic issues which influence environmental outcomes in China, however, have led to the country being referred to as 'the single most important environmental actor on the global stage' (Lewis 2009: 1195).

The Chinese government has responded directly to growing concerns about climate change by issuing a number of laws and regulations, creating new institutions as well as raising the status of existing environmental institutions, formulating policy and campaigns to address the issue, and engaging in negotiations and research at international level, most notably through the UNFCCC (United Nations Framework Convention on Climate Change) and the IPCC (Intergovernmental Panel on Climate Change). ${ }^{1}$ Concurrently, the Chinese media, academics, NGOs (NonGovernmental Organisations), and civil society groups have shown a steadily increasing interest in climate change and environmental issues in the last two decades, with a rapidly growing number of media articles, academic reports, and NGOs working on climate and environmental issues (Grumbine and Xu 2011; Painter 2010). ${ }^{2}$ At the same time, the Chinese public has become more aware and more concerned about climate change and other environmental issues, as evidenced by the jump in environmental protests over the last decade. ${ }^{3}$

China's vital role in global efforts to combat climate change, especially in view of the rate and scale of China's environmental impacts on natural ecosystems from local to international levels (Weller 2006; Hathaway 2010; Blaikie and Muldavin 2004), creates a pressing challenge to explore the unique characteristics of Chinese environmental values and policy, as well as the frames that are employed to understand climate change and related environmental issues domestically.

1 For a more detailed overview of Chinese government actions, see Blaikie and Muldavin 2004: 528-529. For a comprehensive list of Chinese environmental laws and policies, see Zhang and Wen 2008: 12511252.

2 The increased coverage of these issues within state-controlled media and academic institutions could also obviously be at least partly attributed to government agendas.

3 The Ministry of Environmental Protection recorded 51,000 environment and pollution related protests in China in 2005 - a 29 percent increase from 2004 (cited in Economy 2005: 131). 
Several studies have previously addressed the need for detailed studies on Chinese mental encounters with the environment. These works tend to deal with a single case study each time. Many look at a particular group within the population, such as the media (Internews 2013), international environmental NGOs operating in China (Hathaway 2010), or coal miners and mine owners (Hong and Jie 2013). Others focus on a single geographical region, such as the Himalayas (Blaikie and Muldavin 2004) or a township in Inner Mongolia (Hong 2006). Most notable are the works of Mertha (2008) and Matsuzawa (2011) on anti-dam movements, and Jun Jing (2003) and Ma Tianjie (2008) on environmental protests in rural China. Regarding the more latent frames of non-movement activists, Julia Broussard uses the comparable method of cultural discourse analysis to evaluate the underlying 'cultural schemas' relating to the environment of a group of female participants in an environmental programme run by an international NGO in a rural area of northern China (Broussard 2009).

With regards to the theory of frame analysis employed within this paper, although ultimately drawn from the initial work of Erving Goffman (1974), the approach utilised here relies more heavily on the works of William Gamson (1988; 1992; Gamson and Modigliani 1989) on the social psychology of framing, which classifies frames as 'central organizing ideas ... for making sense of relevant events, suggesting what is at issue' (Gamson and Modigliani 1989: 3). Gamson sees frame analysis as a tool to understand the meaning systems available to people in a general everyday context - in this he remains true to Goffman's definition of frames as allowing individuals to 'locate, perceive, identify, and label a seemingly infinite number of concrete occurrences' (Goffman 1974: 21). Conversely, the methodology used to implement the frame analysis in this paper is drawn from social movement studies, within which frames are defined as a resource used purposefully to pursue strategic goals (Snow and Benford 1992; 2000; Gerhards and Rucht 1992; Ferree et al. 2002).

The most important elements of frames for this paper are what David Snow terms the 'core framing tasks', which fall into three sections. Firstly, the diagnostic element of a frame, which is 'a diagnosis of some event or aspect of social life or system of government as problematic and in need of repair or change; and the attribution of blame or responsibility for the problematized state of affairs' (Snow 2013: 471). The second element of a frame is prognostic, consisting of 'the articulation of a proposed solution to the problem ... and often a refutation of an opponent's current or proposed solutions' (ibid.: 472). Finally, issue frames tend to include a motivational aspect, in the sense of a

call to arms or rationale for action [...] providing prods to action by, among other things, accenting and highlighting the severity of the problem, the urgency of taking action now 
rather than later, the probable efficacy of joining others in the cause, and the moral priority of doing so (ibid.: 474).

These three elements add up to a simple formula for issue framing: a problem (diagnosis), solution (prognosis), and supporting rationale or appeal to principles (motivational). The core frames identified by this paper are set out in this manner. Furthermore, framing strategies employed by various actors are analysed in greater detail in the following sections.

The current research is an attempt to contribute to our currently limited understanding of the complex cultural and political contexts that motivate actions and responses to these issues within the domestic sphere in China. Through in-depth interviews and focus groups conducted between 2011-13 in Běijīng 北京, Shànghăi 上海, Guăngzhōu 广州, Kūnmíng 昆明 and Gāolígòng Shān 高黎贡山 (Yúnnán 云南 province) amongst a cross-section of Chinese actors, as well as analysis of relevant policy documents cross-referenced against the interview data, ${ }^{4}$ an investigation of the frames applied to the concept of climate change by Chinese citizens from a range of backgrounds and professions has been conducted. It should be noted, however, that the limited scope of this research confines it to an explorative study, which aims to postulate some initial findings rather than provide a definitive categorisation.

This paper investigates: a) how the political context, as well as differing political agendas and policy goals according to which actors operate, affects and sometimes constrains the frames they generally employ; and b) the specific frames used to understand and discuss climate change by interview subjects and in written documents. It finds that different frames are employed by those supporting the current regime and its attendant official discourses on climate change and the environment (mainly government officials) and those challenging or in opposition to such dominant framings (particularly NGOs).

\section{The Political Context}

\section{Government Framing Strategies}

The Chinese Communist Party (CCP) controls not only the political system in China, but also many other institutions and aspects of daily life such as the media, academia, and civil society groups. The media are mainly state-run and subject to government censorship, something that was highlighted by all media professionals

4 See appendices for further information. 
interviewed. ${ }^{5}$ Participants in the media focus group specifically linked media censorship with the competing claims of economic development and environmental protection, particularly in the case of local projects for economic development which have the support of the government but can be controversial because of their effects on local people and the environment:

There is also sometimes pressure from local government, especially regarding projects which are important for local economic development, for example hydropower development. In these cases, the media are told in advance that they are not allowed to report on these stories (MP-FG).

Perhaps more importantly, most journalists made reference to the government officials' common practice of inserting their own stories and messages into newspaper reports, thus actively controlling which news item is published (a framing tactic in itself), and how this news item is framed. This practice was also referred to by both NGO workers and academics, such as the avowal of an academic that

[t]here is little protest from local communities [specifically referring to the building of nuclear power plants] in China because there is less transparency - the government does not tell people things and they tell the media what to say, so the people never know the truth (AD1).

This view was corroborated by a senior editor, who stated that 'the government will contact the newspaper directly when they have messages they want to send to the public, and these will be included in articles' (MP1).

The government also controls the academic sector through systems of funding and patronage, which are dependent on government subsidy. As Michael Hathaway has noted, referring to the lack of oppositional claims to the dominant government framing of climate change:

Few groups were interested in challenging this thesis or exerting the hard work required to offer counter-narratives. This was particularly true for Chinese scientists, almost all of whom were based at state-run institutes and colleges and therefore feared serious reproach if their research challenged the state's conventional wisdom. Of course, some scientists quietly worked against dominant frameworks, but they often found themselves without the publications, grants, and job security gained by peers who embraced such narratives (Hathaway 2010: 443).

5 For an example of government media censorship, see the case of the Southern Weekly (Nánfāng Zhōumò 南方周末) New Year op-ed in 2013 (http://www.nytimes.com/2013/01/07/world/asia/chinese-newspaperchallenges-the-censors.html?_r=0). Journalists at the prominent newspaper's Guăngzhōu head office protested against heavy-handed censorship of the piece by provincial propaganda officials. The article had been calling for political reform, but was altered by officials into a tribute to one-party rule the day before publication. 
Finally, civil society is controlled through diverse but ubiquitous government interventions, such as neighbourhood committees (jūmín wěiyuánhuì 居民委员会), GONGOs (government-organised non-governmental organisations), and government-run charities. ${ }^{6}$ NGOs are also subject to stringent government controls. They must report to the Ministry of Civil Affairs annually on their activities in order to have their license to operate renewed, meaning that their licence can be revoked at any time if their sponsor dissociates from them or the Ministry of Civil Affairs denies their license to operate. NGOs are not permitted to form national networks or have offices in more than one province. ${ }^{7}$ This keeps NGO activity largely smallscale and local in character, and prohibits the creation of a national movement. The NGO focus group summarised the situation by simply saying that 'NGOs in China do not have much power and it is not an easy or financially rewarding occupation' (NGO-FG).

Through these all-encompassing networks and systems, the CCP ultimately maintains a monopoly on sources of power, authority, and legitimacy, and simultaneously disenfranchises and delegitimises potential alternative sources of authority and alternative views. This delegitimisation strategy is evident in one case study of an anti-dam movement in Yúnnán province chronicled by Mertha (2008). Following protests from local communities organised by NGOs criticising the government and hydropower companies involved in the construction of the dam, government authorities retaliated with a counter-framing campaign directly attacking the proponents of the anti-dam movement. Using a pro-government physicist as spokesman, the government engaged in a delegitimisation campaign that framed the opposition and their arguments as irrational, unscientific, elitist, and self-serving. The government physicist derided 'environmentalists' who, he said, 'worshipped nature at the expense of the needs of people' (Mertha 2008: 134). The Yúnnán provincial government, through its systems of direct and indirect control of media, and particularly

6 The charity sector in the PRC is heavily regulated and restricted by the government, with most charitable donations being directed to the Chinese Red Cross, the largest charitable organisation in China. However, the Red Cross has been the subject of several recent corruption scandals (see articles in the South China Morning Post: http://www.scmp.com/news/china/article/1227819/china-red-cross-admits-redirecting-85myuan-donated-2008-sichuan-quake?page=all, http://www.scmp.com/news/china/article/1222416/red-crosssociety-china-reopen-guo-meimei-scandal) which have caused the public to lose confidence in the organisation. As one interviewee noted, 'donation is not popular in China' (NGOW5).

7 Similarly, an NGO worker, who works within the media sector, noted at interview that 'official journalist networks are controlled by the government and therefore not much used by journalists. Unofficial journalist associations are prohibited but online channels and networks are often used by journalists to keep in contact and pick up stories' (NGOW4). 
academics, was largely able to silence any meaningful critical voices within the reach of their authority. ${ }^{8}$

The government thus maintains a virtual monopoly on scientific knowledge. Because scientific knowledge is effectively under the control of the authorities, engaging in a scientifically informed debate is almost impossible for NGOs or local communities affected by government projects - as Mertha comments, using a Foucauldian insight, 'knowledge really is power' (2008: 147). This situation is exploited by the government to maintain its hegemony over issue frames domestically. By delegitimising NGOs, or not allowing them the space and resources to gain credibility, the government simultaneously delegitimises their discourses and frames. As Snow (2013) has noted, the perceived credibility of the source or claims-maker is a crucial element deciding whether a frame is accepted by its intended audience.

Antagonisms between government and NGOs are evident in government actions aimed at limiting and controlling NGO activity. This antipathy and distrust on the part of the government is partly explained by the history of NGOs in other parts of the world and the foreign influence on many NGOs through their international networks and sources of funding. An NGO worker explained that

Chinese NGOs often work with international partners; however the Chinese government doesn't like this. International Rivers, for example [an international NGO] - their website is blocked in China because it contains information about the potential risks and disadvantages of government projects such as dams, and strategies to mobilise people against government policy (NGOW1).

The NGO worker here addresses the underlying cause of the government's hostility towards Chinese NGOs. Their cooperation with international partners opens the door for alternative frames that are in direct opposition to the Chinese governmentparticularly those from democratic countries, where civil society is allowed to flourish and popular protest is routinely used as a tool to hold government to account. The CCP depends on its control of frames and monopolisation of framing resources to maintain its power and authority within Chinese society. The articulation of alternative frames is thus a direct threat to CCP control, which cannot be tolerated by the government.

Therefore, the CCP to a large extent monopolises avenues and resources, which in a liberal democracy, would be utilised by social movement actors for generating and amplifying alternative or oppositional frames. Individuals and groups who

8 The anti-dam campaign in Yúnnán initially succeeded in halting the construction of the planned dams, with government officials agreeing to complete more thorough Environmental Impact Assessments (EIAs) and consult with local people. It became clear, however, that this was an appeasement strategy designed by the government to defuse the protests - and thus ensure social stability - in the short term. In 2011, preparations for the construction of the dams were quietly resumed, avoiding much of the negative publicity and public protest that had previously encountered. 
question, criticise, or oppose government frames - or formulate alternative framesare placed under extreme pressure to conform with government orthodoxy, and penalised severely for even minor deviations from CCP ideology. Such repressive government tactics notwithstanding, proponents of subversive discourses are routinely discredited in an attempt to delegitimise their heterodox frames and maintain government hegemony over framing resources.

\section{NGO Framing Strategies}

This political environment is clearly not overly conducive for the formation of a critical opposition movement and significantly limits the scope of NGO, media, academic, and civil society activities and their ability to produce and disseminate dissenting frames. Organisations and individuals with dissenting views have, however, devised strategies (with varying levels of success) for getting around government restrictions on their activities, and have produced salient counter-frames expressing their disagreement and discontent with government policies and proposing alternative solutions whilst not challenging or criticising the government explicitly, which would invite repression and reprisals.

In an article analysing the frames employed by activists in the 1989 Tiān'ānmén 天安门 democracy protests, ${ }^{9}$ Zuo and Benford (1995) have shown that the success of oppositional frames in the Chinese context relies heavily on the ability of claimsmakers to subvert and modify pre-existing official frames in order to create a new set of meanings and associations undermining the intent of their original significations. In other words, activists must work within official frames rather than directly challenging them, or attempting to create wholly new frames, or transplanting foreign frames-which often lack salience within a Chinese political and cultural context.

In support of this argument, Zuo and Benford further identify three key frames, already present in Chinese politics and culture, which were usurped by the 1989 democracy movement in order to legitimate their protest: Confucianism, nationalism, and communism. However, they also note that the importance of these frames is derived from more basic beliefs emanating from traditional Chinese culture and values - namely loyalty, obedience to superiors, and collectivism - which all three ideologies in some way draw on in their internal logic systems. These values originate with Confucianism, but under communism have been translated into 'devotion to communist practices in China' (Zuo and Benford 1995: 139), and by extension

9 This line of argumentation is also followed by Hong (2006) on Mongolian villagers' responses to the enforcement of government policies controlling their traditional pastoral lifestyles during the Máo era. 
loyalty and obedience to communist leaders and the communist state (nationalism).$^{10}$

Thus, successful NGOs, media professionals, and academics commonly frame dissenting views as attempts to 'help' the government in a loyal and patriotic sense; for example, an NGO may frame its activities as supporting government policy implementation amongst rural or isolated communities, or monitoring industry to make sure companies' environmental standards are in line with government regulations. This strategy is evidenced by a project related to environmentally friendly banking and ethical investment recounted during the NGO focus group:

The Chinese government has policies to encourage Green Banking and ethical investment, but they are not often implemented by the banks themselves. NGOs can help to monitor the banks, initiate action, support banks in green banking, and hold them to account. The main focus is on loans, I mean, whom the loans are going to-heavy polluting industry or green manufacturing companies. We have a website dedicated to monitoring banks and providing public information on the banks' activities, which also has a forum for general public comments and discussions. This project also has government support as it itself supports government policy through its monitoring role (NGO-FG).

Such so-called 'win-win' framings allow NGOs to develop and operate without the constant threat of government reprisal, as well as to gain crucial support from government and affiliated organisations that control flows of funding, patronage, and access. One savvy director of an international NGO operating in China highlighted the importance of such messaging, saying that

[i]t is important to understand communication strategies and messaging in China, for example 'Harmonious Society' messaging - framing a project as promoting a harmonious society is most successful. Framing and language are very important. 'We are here to help you' messaging is most successful, for example, helping companies save money, helping government reach its targets (NGOW3).

This monitoring role has also been extended by activists to monitoring of local government. Although the political opportunity structures under the authoritarian rule of the $\mathrm{CCP}$ are severely limited, activists have identified certain fissures within the monolithic government machinery which can exploit to their advantage. ${ }^{11}$ One such rift is between central and local government (Ran 2009) - a divide which NGOs in particular have utilised to further their own agendas at both local and

10 An extreme example being the Máo personality cult, which inspired the blind devotion of the Red Guards as young loyalists during the Cultural Revolution.

11 As in the 'fragmented authoritarianism' model of Chinese governance, first proposed by Lieberthal and Oskenberg (1988), and which was revisited recently by Mertha (2009), who argues that the framing is a key strategy employed by those attempting to exploit the fragmentations in the Party machinery (whom he terms 'policy entrepreneurs'), and their ability to frame the issue effectively is often decisive in whether their suit is ultimately successful. 
national levels. By framing local government as corrupt, disloyal, or negligent in not implementing central government policy, and concomitantly framing their own activities as supporting the policies of the central government, such groups can appropriate official discourses of loyalty, obedience, and patriotism for their own causes, framing themselves as patriotic in uncovering and bringing to the attention of the central government the failings of local bureaus in implementing their policies.

One NGO leader employed this framing tactic several times in a single interview, most notably in the following excerpt, where he states that

[t]he Minister of Water Resources met with me, and the environmental leader also met me. And also the Ministry of Construction, who take care of World Heritage sites, met me. They say what I do is good and that I help take care of the river. But the provincial government says we are very bad. We have become very controversial (NGOW1).

He also spoke at length on the failings of local government, arguing that the one in Yúnnán purposefully conceals the real consequences of dam construction on the local environment from the local population in order to avoid protests. He argued that local governments are self-serving and deceive local populations, particularly in the case of dams and hydropower projects.

For example, building a hydropower station increases tax revenues and GDP, which is good for the local government. However, it does not help the local people because most people employed in hydropower stations need specialist technical knowledge, which is not readily available in the local communities. The enterprises themselves are usually based in other provinces such as Běijīng, Guăngdōng, Zhèjiāng or Jiāngsū, therefore they do not help local industry or give back to local economy. And the local communities have to deal with the environmental problems and pollution caused by energy manufacturing. However the public is not aware of this - they are simply told by the local government that these plants will bring development and that that is a good thing (NGOW1).

Again, the framing of local government below is as greedy and ambitious - they 'only care about GDP' and what is 'good for their careers'.

The local government has plans to develop coal mining and nuclear power in the province [Yúnnán] - they do this because they only care about GDP, because that is what they are assessed on politically and it is good for their careers. It is not a question of knowledgethey are aware of environmental risks but do not see them as a priority (NGOW1).

Thus, local governments are framed as causal agents for the lack of priority given to both environmental issues - such as climate change - and the real needs of local communities under their jurisdiction. This framing constructs a visible target for local communities impacted by the effects of climate change, which aids mobilisa- 
tion and makes the claims of environmental NGOs seem more credible amongst their target audiences. ${ }^{12}$

The strength of this frame for NGO activities is in its resonance with wider Chinese society. Li (2004) has demonstrated through interviews with villagers in China that many rural Chinese in particular believe that there are substantial differences between central and local government, and have higher levels of trust in the former; they 'trust that the Centre's intent is beneficent but distrust its capacity to ensure faithful implementation of its policies' (Li 2004: 228). This frame, with its combination of trust in the central government's intent and distrust in local government's ability or willingness to carry it out, may encourage villagers - particularly when supported and incited by NGOs or other dissenting groups - to defy local officials in the name of loyalty to the central government and patriotism to the state (ibid.: 228).

The success of this frame, therefore, is not only due to its utilisation of the fragmented nature of the Chinese political system, as in a political opportunity structure model, but also in its ability to exemplify the critical importance of culture in the framing process. For frames to be successful, they must resonate with pre-existing cultural beliefs and values prevalent in the society in which they are implemented (Snow and Benford 1992; 2000).

Following this contextualisation of framing strategies and processes within the PRC, the next section will outline the specific frames evinced through interviews and focus groups conducted with relevant actors and analysis of documents produced by proponents of these competing frames.

\section{The Frames}

\section{Climate Change and Development}

Development was found to be by far the most dominant frame associated with the concept of climate change amongst the interview subjects. ${ }^{13}$ References to the relationship between development and climate change and the interaction between the two concepts was ubiquitous amongst both the interview subjects and in the documents analysed. However, the way in which the concept of development itself was framed varied markedly between different groups, and most notably between representatives of government and NGOs.

12 Following the arguments of Snow (2013: 472) on prognostic framing and blame attribution.

13 Minor frames included a purely 'scientific' frame and an 'international relations' frame. However, these were employed by only a small minority of interview subjects-and was done so inconsistently. These frames will therefore not be considered in detail in this paper, in order to provide a more thorough analysis of the major frame of development. 
Government officials consistently adhered to the principles of 'ecological modernisation' - a political concept explored in more detail below. They viewed economic development as ultimately a priority over environmental issues, were vehemently regarding China's right to development, and supported scientific and technological solutions. NGO workers tended to advocate more for an alternative vision of development, prioritising conservation, application of the precautionary principle, the rights of local communities, and the value of traditional knowledge of indigenous populations and 'low-tech' solutions.

The characteristics and framing components of these two divergent approaches are outlined (Figure 1 and 2) and discussed below.

\section{The Dominant Frame: Ecological Modernisation}

Two policies, Scientific Outlook on Development (kēxué fāzhăn guān 科学发展观) and Ecological Civilisation (shēngtài wénming 生态文明), along with a third, building a Socialist Harmonious Society (shèhuì zhùyì héxié shèhuì 社会主义和谐 社会), defined the core policy structures of the Hú-Wēn 胡-温 administration (2003-13). The development policy of the Hú-Wēn administration was characterised by a strong emphasis on 'sustainable development', 'circular economy', and 'lowcarbon development', ${ }^{14}$ with greater concern evinced for environment and social issues as part of the wider national development strategy than in previous administrations.

Speaking on the concept of Ecological Civilisation at the 18th National Congress in 2012, Hú referred to the centrality of development and modernisation efforts to the policy and ideology of the administration. He stated that

[w]e must give high priority to making ecological progress and incorporate it into all aspects and the whole process of advancing economic, political, cultural, and social progress, work hard to build a beautiful country, and achieve lasting and sustainable development of the Chinese nation. ${ }^{15}$

14 These terms are common in government discourse; for example, Hú's speech at the opening of the 18th National Congress on November 8, 2012 (China Focus 2012), and the NDRC's 'Outline Plan for the Reform and Development of the Pearl River Delta 2008-2020' (Wilson Center 2011). These terms as government discourses were also referenced directly by an interview subject working at an international NGO, who stated that 'messages have changed over time in line with Chinese government policy, from environmental protection, to circular economy, to ecological civilisation, to sustainable development, to low carbon development and low carbon economy' (NGOW3).

15 Hú Jintāo, speaking at the opening of the 18th National Congress on November 8, 2012 (China Focus 2012). 
Figure 1 Ecological Modernisation Frame

Frame I: Ecological Modernisation

Core frame: China's development should follow as environmentally-friendly or 'sustainable' a path as possible, but ultimately economic development is the priority; China must modernise at all costs.

Causes of environmental problems [diagnostic]:

1) West/developed countries (historical emissions; high per capita emissions; 'luxury emissions'; siting factories in China);

2) Primitive/backwards environmental practices of poor/rural/minority populations;

3) China is in an early stage of development and environmental damage, and emissions are to an extent necessary for its development.

Responsibility/responsible agents [diagnostic]:

Developed countries are ultimately responsible and therefore governments of developed nations have a responsibility to aid developing countries such as China.

Domestically, the Chinese government is responsible for both economic development and climate change mitigation and adaptation measures.

Consequences [diagnostic]:

China will face increasing pressures on water, food, and energy security, which could in turn jeopardise social stability and national security.

Proposed solutions [prognostic]:

1) Science and technology;

2) Development, raising incomes and living standards;

3) Large-scale government campaigns and projects.

Appeals to principle [motivational]:

Progress, authority, the greater good, patriotism.

The reference to 'ecological progress' frames ecological issues, along with 'economic, political, cultural, and social' issues, squarely within a development frame, as consisting of institutions and practices which must be modernised in the name of 'progress'.

As may be noted from such sweeping statements, these key 'policies' are in fact incredibly broad and lack any real detail of how they are to be implemented in 
practice. ${ }^{16}$ Their function, in the terminology of this paper, is rather to provide a frame within which more detailed policy and regulations must be formulated. They form the pinnacle of a policymaking structure that descends directly and hierarchically from top ranking officials down to local cadres (as well as horizontally across ministries).

The importance of such key policies is thus in their influence in directing policy formulation and implementation at all levels throughout the Chinese government, and in framing political, economic, and social issues under their strictly delineated auspices. This correlation is evidenced by the responses of the government official group at interview. The vast majority of officials adhered strongly and uncritically to these frames ${ }^{17}$ - thus an official from the central Ministry of Water Resources (GO2) stated that she would 'follow political views' and use 'data and information provided by the Party' as sources.

The dissemination of the dominant government-backed frames from central to local level is shown explicitly in the interview data collected in a rural area of Yúnnán province, amongst both government officials and local farmers. Here, the modernisation and development frame espoused by the central government was found to be central to local people's understanding of climate change. Both their stated views at interview and their practical implementation of government policies evidenced a strong correlation with government frames, stressing that only through modernisation and development could China combat climate change.

One high-level local official (GO5) directly referenced the government policy of Ecological Civilisation - when questioned regarding which sources he trusted and would use for information on climate change, he responded that he would look to such government policies for guidance when formulating policy at the local level. Further, he recounted that the local government had set up agricultural research stations in the local villages that used scientific research methods to research suitable crops for farmers to plant. This approach also shows the government emphasis on modern scientific research, data, and techniques in agriculture-which it terms ecological modernisation. Such political realities are important in understanding the central role of government in not only the framing of climate change at a discursive or policy level, but in the articulation and application of these frames in practical aspects of the lives of the Chinese population.

Within these highly centralised, authoritarian, and hierarchical Chinese government structures, a single central government agency plays a crucial role as the principal coordinating body on both domestic and international climate change

16 Xīnhuá 新华, the official Chinese state news service, reported (Xinhua 2012) that Hú gave the definition of the goals of the Scientific Outlook on Development as 'freeing up the mind, seeking truth from facts, keeping up with the times and being realistic and pragmatic', a typically broad and vague policy statement.

17 In China, this is referred to as zūnxún dăng de lùxiàn 遵循党的路线 or 'toeing the Party line'. 
policy in China: the National Development and Reform Commission (NDRC) (Guójiā Fāzhănhé Găigé Wěiyuánhuì 国家发展和改革委员会). A majority of government officials made reference to NDRC when asked who they worked with on climate change issues.

As NDRC's remit is ultimately concerned with economic development, peripheral issues, such as climate change, often come to be conceived of in terms of development and incorporated into pre-existing frames. ${ }^{18}$ The most explicit statement of climate change as a development issue comes from the Foreword to China's National Climate Change Programme (CNCCP) (Zhōngguó yìngdui qìhòu biànhuà guójiā fāng'àn 中国应对气候变化国家方案), a key policy document issued by NDRC in June 2007. Being the first official statement specifically focused on climate change issued by NDRC, in its first two sentences we read: 'Climate change is a major global issue of common concern to the international community. It is an issue involving both environment and development, but it is ultimately an issue of development' (NDRC 2007).

Framing climate change as a development issue within the remit of NDRC also has further consequences through its subsequent positioning within wider government frames. Most notably, climate change has come to be framed within the official government discourse in terms of food, water, and energy security (Zhang 2009: 209). Six of the eight government officials interviewed referred to the effects of climate change on agriculture and food production, whilst seven referred to drought as one of the severest impacts of climate change in China. This framing is evident in the following statement made by a high-level NDRC official.

\begin{abstract}
Based on China's National Assessment Report on Climate Change released in 2006, climate change mainly influences China in terms of agriculture, water resources and natural ecological systems, and may cause greater instability of agricultural production, more severe flood disasters in the south, and exacerbated demand-supply conflict of water resources in the north (NDRC 2009).
\end{abstract}

An official interviewed from the NDRC (GO3) provided the most explicit and extensive description and rationalisation of this framing amongst the government officials interviewed. He first referred to $\mathrm{CNCCP}$ - which in itself highlights the centrality of NDRC in controlling the articulation of climate change discourse in China - and the emphasis placed on 'water saving technology' (advocating a technological solution to the problem) because of 'severe water resource issues', which are 'particularly bad in China compared to the rest of the world, and particularly bad

18 The shaping of new discourses to fit pre-existing frames by governments and other powerful normative agencies is examined by Walker 2009.

19 Xiè Zhènhuá 解振华, Vice Chairman of the National Development and Reform Commission, Report of the State Council on Responding to Climate Change, speech given at the 10th Meeting of the Standing Committee of the 11th National People's Congress, 2009. Reproduced in NDRC 2009. 
in the west of China'. He then goes on to link water, food, and energy security issues, stating that

[e]nergy and water issues are closely related. For example, the processes of turning coal into gas or oil. The advantage of this from a government perspective is that it helps protect energy security by providing more oil and gas, which China does not have much of naturally, so that China does not rely too heavily on imports. The advantage from a business perspective is that this can be very profitable, especially if international oil prices increase. However, these processes use an extremely large amount of water, adding to China's water resource scarcity issue(s). The central government therefore has only allowed 5 or 6 projects of this kind in China. Hydropower, biofuel and biomass also have similar problems. People are concerned that if crops are used for energy production this will impact on food security. Agricultural, water resource and other issues can all be solved by tackling climate change - this is the fundamental issue (GO3).

This statement parallels the framing of climate change evident in the document to which he explicitly refers, that is CNCCP. Despite its breadth, the Program largely defines China's climate policy through the lens of energy-energy efficiency, energy savings, energy technology, and renewable energy. This frame was further codified by the Resolution of the Standing Committee of the National People's Congress of China on Actively Responding to Climate Change, adopted at the Tenth Meeting of the Standing Committee of the Eleventh National People's Congress on 27 August 2009, which again focuses on energy issues, stating that

[e]fforts should be made to enhance energy conservation, increase energy efficiency and improve energy structure. It is important to adhere to the approach of building up the capacity of emissions control and adaptation through scientific and technological advances and innovation. It is important to promote energy conservation and emissions reduction through economic restructuring and industrial upgrading (NDRC 2009).

This framing not only leads to attention being concentrated on these specific issues at the expense of others, but also associates the concept of climate change with security issues. Such a framing, as can be seen from the views of government officials expressed above, ultimately relates climate change, energy security, and economic stability within the same master framework (Ma 2008: 33). Elizabeth Economy (2005: 156) further quotes former Minister of Environmental Protection Zhōu Shēngxián 周生贤 (b. 1949) as saying that 'with the increase of environmental mass incidents, environmental issues have become the primer for social instability', thus linking the issue with social as well as economic stability.

In accordance with the priority given to economic development and modernisation in government discourse, opponents of the official development discourse or proponents of alternative ones are stigmatised in various ways in order to uphold the legitimacy of dominant, government-promulgated framings of the issue. The most dominant framing of such dissenters - or of any persons perceived as obstacles to 
government modernisation programmes - is either simply as hysterical and irrational (Čapek 1993: 7) or as 'ignorant and unscientific' in their practices or beliefs (Hathaway 2010: 446). One official interviewed argued that the 'inefficient and sometimes damaging land use practices' of uneducated rural villagers were detrimental to the environment and needed 'reform' implemented by the government (GO7). The role of the state, under this framing, is "to transform "backward" rural dwellers into scientific citizens, or at least ones more productive and less ecologically harmful' (Hathaway 2010: 446).

This frame is also clearly evident in an interview conducted with a local village chief (GP1), a crucial node in the implementation of central and local government policy and dissemination of not only information, but also the framing of issues espoused by the government. The chief is leader of a Hàn (Hànzú 汉族) village in a rural area of Yúnnán province with a high minority population in surrounding areas.

The Lìsù minority traditionally live in the forest and live by hunting. However, now they have been educated they see that they can live better by protecting the forest and planting crops. Now they plant coffee along with the Hàn villagers. Some have gone back to the forest but not many (GP1).

Here, as in many other cases, the Hàn Chinese norm of a settled agriculturalist community with specific social and environmental beliefs and values is forcibly imposed on minority groups whose traditional lifestyles and practices are markedly different, such as nomads, pastoralists, and other groups, such as the Lìsù (Lìsùzú 傈 僳族) with nonmarket, subsistence-oriented resource use strategies and concomitant environmental frames.

The government thus sees its role as forcing the Chinese population to accept modernisation and its own scientific development frame because it is ultimately for their own benefit not only in protecting the environment, but also in raising incomes and improving standards of living. Many government officials referred to poverty as a more pressing issue than climate change and environmental protection, particularly for poor sections of the population. This is reflected in comments such as "people still struggling to make a living cannot have these concerns [for climate change/the environment]' (GO4), and 'most people in China are not concerned about climate change because they are still very poor and more concerned about having enough to eat' (GO1).

Such statements reflect a hierarchy of needs mentality, whereby economic development and concurrent poverty alleviation are more pressing concerns than concepts 
such as climate change and the environment. ${ }^{20} \mathrm{~A}$ statement from a top NDRC official echoes this sentiment: ${ }^{21}$

For our country, a developing country with a low economic development level and per capita GDP only slightly higher than 3,000 US dollars, and a lot of poverty-stricken population, development remains the first priority (NDRC 2009).

Individuals and local communities are strangely and notably absent from government prognostic frames. They should be 'educated' or have their awareness raised (by the government) about environmental issues, such as climate change- but, ultimately, their role is to passively receive information and act on it in the way they are advised to by government rather than actively contribute.

Thus the NDRC documents refer only briefly to the public, and then only in the frame of 'public awareness campaigns' conducted by the government, to which the public are portrayed as receptacles passively receiving government instructions. The 2009 Progress Report on CNCCP, published by NDRC, contains only one paragraph on 'public awareness' in its fifty pages, and 'the public' is not referenced elsewhere in the report.

The Chinese government promoted the environmental awareness of the public in various ways. It organised climate change publicity activities in communities, schools, and villages, and guided the residents to address climate change and lead a low-carbon life (NDRC 2009).

Cities or regions of the country, political and ecological processes, institutions, international negotiations, and scientific data were referred to with far greater frequency than 'people' by government officials in interviews. The inference is that individuals or groups within the population are not as visible or as important within government frames as projects and aggregate figures are. This may also reflect the lack of individual agency accorded to individuals and the collectivist mentality of officials (Douglas and Wildavsky 1983: 90).

20 Following Maslow's hierarchy of needs model, immediate physiological needs such as food and water are more pressing than abstract concerns, such as climate change. Ronald Inglehart (1997; 2005) has further shown that concern for nonmaterial issues (such as climate change) is inversely correlated with the wealth and development level of a given society (although this argument has been challenged by many other scholars, see for example Norgaard 2009).

21 Xiè Zhènhuá, Vice-Chairman, National Development and Reform Commission, speaking at the 10th Meeting of the Standing Committee of the 11th National People's Congress on 24 August 2009. From The Report of the State Council on Responding to Climate Change. Reproduced in NDRC 2009. 


\section{The Oppositional Frame: Civic Environmentalism}

Although the government-sponsored 'official' discourse on climate change appears to dominate the debate and certainly determines the official Chinese position on climate change in the international arena, there also exists an 'unofficial' alternative framing of the issue in terms of conservation, application of the precautionary principle, the rights of local communities, and the value of traditional knowledge of indigenous populations. This frame was advocated in interviews primarily by NGO workers and a subsection of dissident academics, freelance media professionals, and (inconsistently) by some members of the general public.

Representatives of these groups are far more likely to openly and actively contest the hegemonic government framing of climate change in terms of food, water, and energy security and social stability, as well as to oppose the government stance that economic development, ecological modernisation, large-scale projects, campaigns and engineering works, and other scientific and technological solutions are the only viable options for tackling climate change. One outspoken academic expounded this argument for an alternative vision of development most clearly, stating that

[i]t is very difficult to convince people that modernisation and industrial development is not always a good thing, that it is not suitable for some areas of China, and that we don't need heavy industry to improve living standards and generate income (AD2).

The position of this academic, and that inferred by other proponents of this discourse, is not anti-developmental: he still implies the need to 'improve living standards and generate income'. The distinction between this and the government discourse is in the proposed solutions to the interlinked issues of climate change and development. The academic in question, and others with similar views, reject the argument that modernisation and industrial development are necessary components of China's development, even if they may cause some environmental damage and contribute to climate change as China develops. He calls this the 'develop first, clean up later', or the 'pollute now, clean up later' mentality and holds that 'both Chinese academics and the government believe that China must follow this model' (AD2), referring to the dominant framing of climate change and development adhered to by government officials and many academics. This frame was explicitly evidenced in an interview with a government official, who gave the example of his home province of Shanxi, which he said had been 'destroyed' by the coal industry - but, he said, 'you have to understand that the people there need money' (GO4). 
Figure 2 Civic Environmentalism Frame

Frame II: Civic environmentalism

Core position: Development should not be at the cost of loss of natural and cultural heritage or the disadvantage and displacement of individuals and communities (particularly marginalised groups, who are most vulnerable); development and environmental protection policies should take local communities' needs and wishes into account.

Responsibility/responsible agents [diagnostic]:

The Chinese government is responsible for the deterioration of the environment in China and it is not doing enough to protect the environment or address the issue of climate change.

The Chinese government and foreign governments must take a leadership role in addressing climate change but, ultimately, every individual and community is responsible for their actions and effects on the environment and should take appropriate actions.

Causes [diagnostic]:

1) Rampant overdevelopment and overconsumption with a lack of regard for the human and environmental costs;

2) Lack of transparency or accountability and corruption of government officials and industry;

3) Disconnect from nature brought about by modern urban life and modernisation processes.

Consequences [diagnostic]:

Destruction of the natural environment; local populations adversely affected; loss of cultural heritage.

Proposed solutions [prognostic]:

1) Combining science and technology with local/indigenous knowledge;

2) Transparent, inclusive, democratic decision-making and public participation;

3) Working with local communities.

Appeals to principle [motivational]:

Humanity; protecting the weak and marginalised members of society; conservation; cultural heritage. 
The academic in question, however, explicitly stated that he disagreed on this as 'China does not have the time or space to follow this model' (AD2). This statement infers a belief in the potentially catastrophic dangers of climate change on human and natural ecosystems, which he and others of this view also make copious reference to. Another academic, who currently works for an international NGO in China (NGOW2), referred to the concepts of 'tipping points' and the 'feedback cycle', theories current in international climate change discourse and, in particular, amongst those advocating the 'precautionary principle' in formulating responses to climate change (Norgaard 2009; UNEP 2011). This approach highlights the lack of understanding of the overall and cumulative effects of climate change and, therefore, warns that policymakers should undertake stringent precautionary measures to ensure potential crises are avoided. The interviewee invoked this frame in his statement that 'we do not understand enough or focus enough on the links between different impacts, their effects on human systems and the feedback cycle' (NGOW2).

Within this alternative discourse, the dominant government framing of climate change and development is both implicitly and explicitly criticised for prioritising economic, industrial, and urban development, as well as applying the principles of modernisation uncritically and universally, without regard for local conditions and without taking into account the complicated consequences for human and natural ecosystems of such heavy-handed interference.

One of the most striking differences between the mainstream frame and the alternative one is the importance ascribed to individuals and local communities in the discourses of frame proponents. Whereas references to individuals and specific local communities are generally either negative in the official discourse or lacking one, in the oppositional discourse they occupy a central position as the victims of or those more vulnerable to climate change, as well as being granted a more central role as active agents in efforts to address the issue. As one NGO worker succinctly stated, 'it's not about how climate change impacts the agricultural sector, it's about how climate change impacts farmers themselves' (NGOW2).

There are also those affected by government policies, such as resettlement or development projects, or whose traditional culture is being lost-particularly in the case of nomadic or hunter-gatherer peoples, whose lifestyles are threatened by government efforts to force communities into settled land use patterns. One NGO leader referred to Yí (Yízú 彝族) minority villagers in a 'model community' the NGO has developed near Lijiāng 丽江, and another to his organisations work with 'vulnerable people, especially poor people such as Tibetan nomads in Sìchuān 四川' (NGOW1).

Additionally, nature itself is prioritised, in the form of biodiversity and natural ecosystems, which need protection from the onslaught of rapid development and the environmental degradation perceived as inherent to modernisation, such as in the 
oft-cited example of the Three Gorges Dam, and the campaign to preserve the Three Parallel Rivers area of western Yúnnán as a UNESCO World Heritage site. The CCSCCC also highlight these factors in their position papers for both the Copenhagen and Tiānjīn 天津 UN climate change conferences, referring to 'disadvantaged populations' (2009: 2) and 'ecologically vulnerable areas' (2010a: 1), as needing additional support and attention from the government and special consideration in government climate policies.

In the alternative framing advocated by the aforementioned academics and NGO workers, climate change is best addressed through an inclusive approach favouring small-scale solutions working closely with affected communities in a reciprocal manner. In practice, this means both teaching skills for adapting to and mitigating the effects of climate change, and learning from traditional land use models and sustainable environmental protection measures routinely practiced in local and indigenous communities. An NGO worker outlined the disparate prognostic frames employed by government and NGOs:

There are different approaches from the central government, who use national, top-down actions mainly focused on mitigation, and local NGOs and civil society groups who favour community-based, bottom-up action, utilise indigenous knowledge, and focus mainly on adaptation. These two groups simply don't work together (NGOW2).

The bottom-up approach mentioned here draws on individuals and communities as examples of traditional lifestyles and indigenous environmental knowledge, which are portrayed as valuable resources that are being ignored or undervalued by the dominant modernisation paradigm of development. Such development projects are often criticised as leading to misadaptation, which can ultimately cause more harm to the environment than allowing communities to continue their traditional practices. One NGO worker interviewed gave a detailed example, which draws together many of these themes.

Sometimes there are cases of misadaptation due to development, for example planting of cash crops such as rubber which are unsuitable to the local environment, degrade the soil over time and interfere with local ecosystems. Rubber is particularly damaging in watershed regions. Certain regions are more vulnerable to the impacts of climate change than others - for example the Tibetan Plateau. Also in this case the area is poorer and therefore has less capacity to adapt to the impacts of climate change when it experiences them. The government have attempted to 'help' the semi-nomadic agropastoralists to settle and engage in agriculture growing barley. However, this interference has in practice been counterproductive. Whilst these communities have higher incomes, their traditional lifestyle and culture is being lost and they have higher energy needs than previously. Before, they would use dung from their yaks for fuel. However now they do not have yaks and they need to cook their barley to make tsampa [䊏粑; $z \bar{a} n b \bar{a}]{ }^{22}$ so they use turf instead. This

22 A staple Tibetan dish of roasted barley flour, usually mixed with butter tea. 
degrades the grasslands and causes greater indoor pollution, which is a great health risk to these people. This example shows how forced changes to lifestyles can be disruptive and have unintended consequences (NGOW2).

This frame provides an implicit (and sometimes explicit) critique of the dominant government frame and its consequences for individuals, local communities, and marginalised groups in Chinese society. These groups argue that the fundamental flaw in the government approach to climate change responses is that it excludes the public entirely from its consultation and decision-making processes. The government has been strongly criticised by NGO workers, the media, and even academics regarding this lack of avenues for public participation in the policy-making process. An academic outlined the system for academic consultation on government policy and his views on it:

There is a limited space for public feedback to the government, especially for negative assessments of government policy. There are channels for academics to make formal proposals through the CPPCC and NPC but these are o-ten not public information, so the general public does not know about them (AD1). ${ }^{23}$

The participants in the media focus group also referred to such channels, but did not view them as effective, stating that 'people who opposed the Three Gorges Dam wrote reports and submitted papers to the NPC but it makes no difference' (MP-FG). The NGO focus group made a similar supporting statement, saying that 'economic development is a more basic issue and a priority for local governments, and the public does not have enough information to understand the issues' (NGO-FG).

Another NGO worker stated that 'the general public do not have any ownership or buy-in to top-down policies and initiatives' (NGOW3). One of the proposals laid out by the CCSCCC (2010b: 2) is that 'the government should encourage the public and NGOs to participate in policy making processes', an implicit reference to the current lack of public and NGO participation in domestic policy processes.

This same interview subject also refers to a common theme amongst NGO workers regarding the disconnected relationship people have with the land and local environment, and the broader implications of their framing of this relationship for their conceptualisation of more abstract environmental issues, such as climate change. NGO workers (and some media professionals) frequently referred to this concept of a 'disconnect from nature', and attributed the cause to processes of modernisation, urbanisation, and the approach taken to development in China-and,

23 CPPCC refers to the Chinese People's Political Consultative Conference, a political advisory body consisting of delegates from a range of political parties and organisations, as well as independent members. Despite its diverse membership, however, it is in reality largely controlled by the CCP. The NPC is the main Chinese legislative body, which holds annual sessions with roughly 3,000 members, with more regular meetings of the Standing Committee of the NPC, which consists of approximately 150 members. The two are often referred to as the liănghui 两会 or 'two meetings'. 
therefore, implicitly by the Chinese government, which controls this approachwhich frames nature as a resource for humans to use rather than having value in its own right. One interview subject stated in this regard that

[t]he relationship between humans and nature should not be that of object and subjecthumans simply using nature for whatever they want or need. This view is a fundamental problem of modern life- everything must have a use, be a resource (NGOW6).

Whilst another NGO worker agreed, stating that

[o]ur relationship with the earth is not good - sadly when you ask kids they do not know about natural processes, they have never been outside the city or connected with naturethis is a potential problem for the future. They stay at home playing computer gamesthey are distanced from nature. They take it for granted and this is dangerous (NGOW5).

This discourse is tied to the general trend, prevalent in the alternative frame, of criticism towards the prioritisation of modernisation and economic development in Chinese society. Overconsumption and overexploitation of natural resources are seen as the ultimate consequence of such modern (particularly urban) lifestyles and the disconnect from nature they entail.

It has been evidenced in these sections that there are at least two widely disparate framings of climate change and the environment operating in the PRC, and further that the different frames can be seen to be associated with and articulated by specific groups within the state and wider society. The political and cultural context in which these frames have arisen, and which have to an extent shaped the way in which they are articulated, will now be discussed, in order to situate the frames and investigate the influence of their distinctive Chinese context.

\section{Conclusion: Chinese Frames}

This paper has sought to explore the frames extant within a delimited set of actors in contemporary Chinese society, as well as the political factors influencing their formation and articulation. Two opposing frames - termed here the 'Ecological Modernisation' frame and the 'Civic Environmentalism' frame - have been identified and subjected to detailed analysis along with the framing strategies employed by those groups that were found to adhere most strongly to each frame.

This paper has focused on government officials and NGO workers as frame articulators, as these groups were found to occupy more (extreme) oppositional positions than members of other groups, such as academics and media professionals. Media professionals were found to articulate the most balanced frames, often referring to both sides of the debate and not advocating strongly for either. This is also true of academics, who evinced a variety of frames and often did not adhere strictly 
to either one of the two opposing frames explored, but rather oscillated between the two and advocated more strongly for further research, monitoring, and data collection, thus framing the issue in a more 'scientific' frame. The ambiguous frames of media professionals and academics may also reflect their position within Chinese society and politics: whilst not officially or directly within the government, they are nonetheless closely tied to the government apparatus, lacking independence and bound by government agendas.

These examples are given to show that the frames articulated by individuals interviewed for this research were not simply a single set of dichotomously opposed frames, but rather a spectrum that encompasses a wide range of discourses articulated to a greater or lesser extent by interview participants.

Analysis of the political context and framing strategies of two of the groups leads to the conclusion that the processes of claims-making and frame articulation are largely divergent from similar practices in a democratic context, due to the authoritarian nature of the political regime in the PRC. The government monopoly on many forms of power and authority creates significant difficulties for any organised opposition to form. Oppositional frames, therefore, are often not openly critical of the government, but work within government frameworks and reappropriate government discourses to serve their own ends. It should further be noted that this phenomenon is not limited to the framing of climate change and environmental issues, but could potentially be investigated with regards to a range of social problems (as has been shown by Zuo and Benford [1995] concerning the democracy movement), suggesting further lines of enquiry utilising this method.

The small sample size of this study has allowed only an initial exploration of the frames and discourses of climate change and the environment articulated by a limited set of actors within the PRC. Further research is needed to more comprehensively understand the salience of these frames within the wider context of Chinese society. The limited number of interviews with members of the general public provided contradictory information about the frames espoused by members of the population outside the key groups with a greater knowledge, understanding, and interest in climate change issues. A larger pool of participants and different variables of analysis - such as level of education, income, or region-would be required to obtain more conclusive information regarding the detailed frames articulated amongst the general public.

This paper has aimed to provide some preliminary findings regarding the framing of climate change and the environment in China. It is hoped that the conclusions drawn here will encourage greater examination of the complex set of issues relating to discourses on climate change, the environment, and society both within the PRC and internationally, and aid scholars and professionals working in the field by providing a fresh angle from which to approach the topic. The frames employed by both political and social actors in China domestically are clearly of importance, not 
only nationally but also internationally, in determining China's position in global climate politics and international negotiations. The fate of the world ecosystem is intrinsically linked to actions taken in the PRC, and these actions are themselves shaped by the frames used to understand and conceptualise the issue by individuals, such as those discussed in this paper. 


\section{LIST OF ABBREVIATIONS}

$\mathrm{CCP}$

CCSCCC

$\mathrm{CNCCP}$

CPPCC

EIA

GDP

GONGO

IPCC

NDRC

NGO

NPC

PRC

UN

UNESCO

UNFCCC

US
Chinese Communist Party

Chinese Civil Society Coalition on Climate Change

China's National Climate Change Programme

Chinese People's Political Consultative Conference

Environmental Impact Assessment

Gross Domestic Product

Government-Organised Non-Governmental Organisation

Intergovernmental Panel on Climate Change

National Development and Reform Commission

Non-Governmental Organisation

National People's Congress

People's Republic of China

United Nations

United Nations Educational, Scientific and Cultural Organisation United Nations Framework Convention on Climate Change

United States 


\section{REFERENCES}

Blaikie, Piers M. and Joshua S. Muldavin. "Upstream, Downstream, China, India: The Politics of Environment in the Himalayan Region." In Annals of the Association of American Geographers, 94/3, 2004, pp. 520-548

Broussard, Julia T. "Using Cultural Discourse Analysis to Research Gender and Environmental Under-standings in China." In Ethos, 37/3, 2009, pp. 362-389

Čapek, Stella M. “The 'Environmental Justice' Frame: A Conceptual Discussion and an Application.” In Social Problems, 40/1, 1993, pp. 5-24

Douglas, Mary and Aaron B. Wildavsky. Risk and Culture: An Essay on the Selection of Technological and Environmental Dangers. Berkeley: University of California Press, 1983

Economy, Elizabeth. The River Runs Black: The Environmental Challenge to China's Future. Ithaca: Cornell University Press, 2005

Ferree, Myra Marx, William A. Gamson, Jürgen Gerhards, and Dieter Rucht. Shaping Abortion Dis-course: Democracy and the Public Sphere in Germany and the United States. Cambridge: Cambridge University Press, 2002

Gamson, William A. "Political Discourse and Collective Action." In From Structure to Action: Social Movement Participation Across Cultures, edited by Bert Klandermans, Hans-Peter Kriesi, and Sidney Tarrow. Greenwich: JAI Press, 1988, pp. 219-244

Gamson, William A. Talking Politics. Cambridge: Cambridge University Press, 1992

Gamson, William A. and Andre Modigliani. "Media Discourse and Public Opinion on Nuclear Power: A Constructionist Approach.” In American Journal of Sociology, 95, 1989, pp. 1-37

Gerhards, Jürgen and Dieter Rucht. "Mesomobilization: Organizing and Framing in Two Protest Cam-paigns in West Germany." In American Journal of Sociology, 98/3, 1992, pp. 555-596

Goffman, Erving. Frame Analysis: An Essay on the Organization of Experience. Cambridge: Harvard University Press 1974

Grumbine, R. Edward and Xu Jianchu. "Creating a 'Conservation with Chinese Characteristics'.” In Biological Conservation, 144, 2011, pp. 1347-1355

Hathaway, Michael J. "Global Environmental Encounters in Southwest China: Fleeting Intersections and 'Transnational Work'.” In The Journal of Asian Studies, 69, 2010, pp. 427-451

Hong, Jiang. "Poaching State Politics in Socialist China: Uxin Ju's Grassland Campaign, 19581966.” In Geographical Review, 96/4, 2006, pp. 633-665

Hong Zhang and Jie Song. "Human Attitudes in Environmental Management: Fuzzy Cognitive Maps and Policy Option Simulations Analysis for a Coal-Mine Ecosystem in China.” In Journal of Environmental Management, 115, 2013, pp. 227-234

Inglehart, Ronald. Modernization and Postmodernization: Cultural, Economic, and Political Change in 43 Societies. Princeton: Princeton University Press, 1997

Inglehart, Ronald and Christian Welzel. Modernization, Cultural Change, and Democracy: The Human Development Sequence. Cambridge: Cambridge University Press, 2005

Internews. Earth Journalism Network Media Study of Chinese Fisheries Journalism. Hong Kong: Internews, 2013

Jing, Jun. "Environmental Protest in Rural China." In Chinese Society: Change, Conflict and Resistance, edited by Elizabeth Perry and Mark Selden. London and New York: Routledge, 2003, pp. 204-222

Lewis, Joanna. "Climate Change and Security: Examining China's Challenges in a Warming World." In International Affairs, 85/ 6, 2009, pp. 1195-1213

Li, Lianjiang. "Political Trust in Rural China," In Modern China, 30/2, 2004, pp. 228-258 
Lieberthal, Kenneth G. and Michel Oksenberg. Policy Making in China: Leaders, Structures, and Pro-cesses. Princeton: Princeton University Press, 1988

Ma, Tianjie. "Environmental Mass Incidents in Rural China: Examining Large-Scale Unrest in Dong-yang, Zhejiang." In China Environment Series, 10, 2008, pp. 33-49

Matsuzawa, Setsuko. "Horizontal Dynamics in Transnational Activism: The Case of Nu River Anti-Dam Activism in China.” In Mobilization, 16/3, 2011, pp. 369-387

Mertha, Andrew. China's Water Warriors: Citizen Action and Policy Change. Ithaca: Cornell University Press, 2008

Mertha, Andrew. "Fragmented Authoritarianism 2.0: Political Pluralisation in the Chinese Policy Process." In The China Quarterly, 200, 2009, pp. 995-1012

Norgaard, Kari Marie. Cognitive and Behavioural Challenges in Responding to Climate Change. World Bank Policy Research Working Paper No. 4940, 2009

Painter, James. Summoned by Science: Reporting Climate Change at Copenhagen and Beyond. Reuters Institute for the Study of Journalism, University of Oxford, 2010

Ran, Ran. "Environmental Politics at Local Levels in China: Explaining the Policy Implementation Gap and Assessing Implications.” Ph.D. Diss., University of Duisburg-Essen, 2009

Snow, David A. "Framing and Social Movements." In The Wiley-Blackwell Encyclopaedia of Social and Political Movements, Volume 2, edited by David A. Snow. Malden: WileyBlackwell, 2013, pp. 470-475

Snow, David A. and Robert Benford. "Master Frames and Cycles of Protest." In Frontiers in Social Movement Theory, edited by Aldon D. Morris and Carol McClurg Mueller. New Haven: Yale University Press, 1992, pp. 133-155

Snow, David A. and Robert Benford. "Framing Processes and Social Movements: An Overview and Assessment." In Annual Review of Sociology, 26, 2000, pp. 611-639

Walker, Gordon. "Globalizing Environmental Justice: The Geography and Politics of Frame Contextualization and Evolution.” In Global Social Policy, 9/3, 2009, pp. 355-382

Weller, Robert P. Discovering Nature: Globalization and Environmental Culture in China and Taiwan. Cambridge: Cambridge University Press, 2006

Zhang Dongsheng. "Green from Above: Climate Change, New Developmental Strategy, and Regulatory Choice in China.” In Texas International Law Journal, 45/1, 2009, pp. 201-232

Zhang, Kunmin and Wen Zongguo. "Review and Challenges of Policies of Environmental Protection and Sustainable Development in China." In Journal of Environmental Management, 88/4, 2008, pp. 1249-1261

Zuo, Jiping and Robert D. Benford. "Mobilization Processes and the 1989 Chinese Democracy Movement.” In The Sociological Quarterly, 36/1, 1995, pp. 131-156

\section{WEBSITES}

China Focus, “Key Quotes From Hu Jintao's Report to the CPC National Congress”, 2012. Available at http://www.chinausfocus.com/library/government-resources/chineseresources/documents/key-quotes-from-hu-jintaos-report-to-cpc-national-congress-november-82012/, accessed March 2016

Wilson Center, “A Vision of a Green Pearl River Delta: The NDRC's 2008-2020 Outline Plan for the PRD”, 2011. Available at http://www.wilsoncenter.org/sites/default/files/CES\%2011\%20pp.\%20182-215.pdf, accessed March 2016 
Xīnhuá, "Goals of the Scientific Outlook on Development", 2012. Available at http://news.xinhuanet.com/english/special/18 cpcnc/2012-11/08/c_131958919.htm, accessed March 2016 


\section{GLOSSARY}

\begin{tabular}{|c|c|c|}
\hline Băoshān & 保山 & $\begin{array}{l}\text { Prefecture-level city in western Yúnnán } \\
\text { province }\end{array}$ \\
\hline Běijīng & 北京 & Capital city of China \\
\hline Gāolígòng Shān & 高黎贡山 & $\begin{array}{l}\text { Protected area in Băoshān prefectural-level } \\
\text { city }\end{array}$ \\
\hline Guăngzhōu & 广州 & $\begin{array}{l}\text { Capital city of Guăngdōng province, south } \\
\text { China }\end{array}$ \\
\hline Guójiā Fāzhănhé Găigé & 国家发展和改革 & National Development and Reform Commis- \\
\hline Wěiyuánhuì & 委员会 & sion \\
\hline Hànzú & 汉族 & $\begin{array}{l}\text { The Hàn ethnic group, the ethnic majority of } \\
\text { the Chinese population }\end{array}$ \\
\hline Hú-Wēn & 胡-温 & Refers to the administration serving under \\
\hline & & President Hú Jǐntāo [胡锦涛] and Premier \\
\hline & & Wēn Jiābăo [温家宝], 2003-2013 \\
\hline jūmín wěiyuánhuì & 居民委员会 & Neighbourhood committees \\
\hline Kēxué fāzhăn guan & 科学发展观 & Scientific Outlook on Development \\
\hline Kūnmíng & 昆明 & $\begin{array}{l}\text { Capital city of Yúnnán province, southwest } \\
\text { China }\end{array}$ \\
\hline Liănghuì & 两会 & $\begin{array}{l}\text { lit. 'two meetings'; reference to CPPCC and } \\
\text { NPC }\end{array}$ \\
\hline Lìjiāng & 丽江 & $\begin{array}{l}\text { Prefecture-level city in northwest Yúnnán } \\
\text { province }\end{array}$ \\
\hline Lìsùzú & 傈僳族 & The Lìsù ethnic minority of Yúnnán province \\
\hline Nánfāng Zhōumò & 南方周末 & $\begin{array}{l}\text { Southern Weekend, a Guăngdōng-based } \\
\text { national newspaper }\end{array}$ \\
\hline Shànghăi & 上海 & $\begin{array}{l}\text { Municipality and port city in central-eastern } \\
\text { China }\end{array}$ \\
\hline $\begin{array}{l}\text { Shèhuì zhǔyì héxié } \\
\text { shèhuì }\end{array}$ & $\begin{array}{l}\text { 社会主义和谐社 } \\
\text { 会 }\end{array}$ & Socialist Harmonious Society \\
\hline Shēngtài wénmíng & 生态文明 & Ecological Civilisation \\
\hline Sìchuān & 四川 & Province in southwest China \\
\hline Tiān’ānmén & 天安门 & $\begin{array}{l}\text { Lit. 'Gate of Heavenly Peace', the entrance to } \\
\text { the Imperial City in Běijīng }\end{array}$ \\
\hline Tiānjīn & 天津 & Municipality and port city in northeast China \\
\hline Xiè Zhènhuá & 解振华 & $\begin{array}{l}\text { Vice Chairman of the National Development } \\
\text { and Reform Commission }\end{array}$ \\
\hline Xīnhuá & 新华 & Official Chinese news agency \\
\hline Yízú & 彝族 & The Yí ethnic minority of southwest China \\
\hline Yúnnán & 云南 & Province in southwest China \\
\hline Zānbā & 糌粑 & Tsampa (see note 22 ) \\
\hline $\begin{array}{l}\text { Zhōngguó yìngduì } \\
\text { qìhòu biànhuà guójiā } \\
\text { fầng'àn }\end{array}$ & $\begin{array}{l}\text { 中国应对气候变 } \\
\text { 化国家方案 }\end{array}$ & $\begin{array}{l}\text { China's National Climate Change Pro- } \\
\text { gramme (CNCCP) }\end{array}$ \\
\hline $\begin{array}{l}\text { Zhōu Shēngxián } \\
\text { zūnxún dăng de lùxiàn }\end{array}$ & $\begin{array}{l}\text { 周生贤 } \\
\text { 遵循党的路线 }\end{array}$ & $\begin{array}{l}\text { Former Minister of Environmental Protection } \\
\text { 'toeing the Party line' }\end{array}$ \\
\hline
\end{tabular}




\section{APPENDIX I: DOCUMENTS ANALYSED}

CCSCCC. 2009. "Chinese Civil Society on Climate Change: Consensus and Strategies", position paper released ahead of the UNFCCC COP15 conference in Copenhagen. Available at http://www.eu-china.net/english/Resources/Chinese-Civil-Society-Coalition-on-ClimateChange_2009_Chinese-Civil-Society-on-Climate-Ch.html, accessed August 2015

CCSCCC. 2010a. "Green China - Race to the Future: Chinese NGOs' Position Paper for 2010 United Nations Climate Change Conference in Tianjin", position paper released ahead of the UNFCCC con-ference in Tianjin. Available at http://www.eu-china.net/english/Resources/EUChina-Civil-Society-Forum_2010_Green-China-Race-to-the-Future.-Chineswe-NGOsPosi.html, accessed August 2015

CCSCCC. 2010b. "Green China - Racing to the Future: Chinese NGOs' Position Paper for the 2010 United Nations Framework Convention on Climate Change in Cancun", position paper released ahead of the UNFCCC COP16 conference in Cancun. Available at http://www.euchina.net/english/Resources/EU-China-Civil-Society-Forum_2010_Chinese-NGOs-PositionPaper-for-the-2010-United-Nations.html, accessed August 2015

NDRC. 2007. "China's National Climate Change Program", available at http://www.china.org.cn/english/environment/213624.htm\#7, accessed August 2015

NDRC. 2009. "China's Policies and Actions for Addressing Climate Change: The Progress Report 2009”, available at http://www.cchina.gov.cn/WebSite/CCChina/UpFile/File571.pdf, accessed August 2015 
APPENDIX II: INTERVIEW DATA

\begin{tabular}{|c|c|c|c|c|c|c|}
\hline Code & Sex & Organisation & \begin{tabular}{|c|} 
Type of \\
interviewee
\end{tabular} & $\begin{array}{c}\text { Type of } \\
\text { interview }\end{array}$ & $\begin{array}{c}\text { Place of } \\
\text { interview }\end{array}$ & $\begin{array}{c}\text { Date of } \\
\text { interview }\end{array}$ \\
\hline GO1 & M & $\begin{array}{l}\text { Department of Epidemiology, } \\
\text { China Centre for Disease Control } \\
\text { and Prevention (CDCP) }\end{array}$ & GO & II & Běijīng & 04.05 .2011 \\
\hline $\mathrm{GO} 2$ & $\mathrm{~F}$ & $\begin{array}{l}\text { Hydrology Bureau, Ministry of } \\
\text { Water Resources (retired) }\end{array}$ & GO & II & Běijīng & 06.05 .2011 \\
\hline GO3 & M & $\begin{array}{l}\text { CDM Project Management Centre, } \\
\text { Energy Research Institute, NDRC }\end{array}$ & GO & II & Běijīng & 09.05.2011 \\
\hline GO4 & M & $\begin{array}{l}\text { National Climate Centre, China } \\
\text { Meteorological Administration }\end{array}$ & GO & II & Běijīng & 10.05 .2011 \\
\hline GO5 & M & $\begin{array}{l}\text { Băoshān Administration Bureau of } \\
\text { Gāolígòngshān Nature Reserve, } \\
\text { State Forestry Administration }\end{array}$ & GO & II & $\begin{array}{l}\text { Băihuālǐng, } \\
\text { Gāolígòngshān, } \\
\text { Yúnnán }\end{array}$ & 12.06 .2011 \\
\hline MP1 & $\mathrm{F}$ & Běijīng Evening News & MP & II & Běijīng & 24.05 .2011 \\
\hline $\begin{array}{l}\text { MP- } \\
\text { FG }\end{array}$ & $\begin{array}{l}\mathrm{M} / \\
\mathrm{F}\end{array}$ & $\begin{array}{l}\text { Freelance journalist; Yúnnán } \\
\text { Daily; Yúnnán Traffic Radio; } \\
\text { national satellite TV station }\end{array}$ & MP & FG (4) & $\begin{array}{l}\text { Kūnmíng, } \\
\text { Yúnnán }\end{array}$ & 13.06 .2011 \\
\hline AD1 & M & $\begin{array}{l}\text { School of Environmental Sciences } \\
\text { and Ecological } \\
\text { Restoration and School of Life } \\
\text { Sciences, Yúnnán University } \\
\end{array}$ & $\mathrm{AD}$ & II & $\begin{array}{l}\text { Kūnmíng, } \\
\text { Yúnnán }\end{array}$ & 13.06 .2011 \\
\hline AD2 & M & $\begin{array}{l}\text { College of Environmental Science } \\
\text { and Engineering, Kūnmíng } \\
\text { University of Science \& Technol- } \\
\text { ogy }\end{array}$ & $\mathrm{AD}$ & II & $\begin{array}{l}\text { Kūnmíng, } \\
\text { Yúnnán }\end{array}$ & 13.06 .2011 \\
\hline $\begin{array}{l}\text { AD- } \\
\text { FG }\end{array}$ & M & $\begin{array}{l}\text { CAAS; NDRC; CASS; CAAS; } \\
\text { CAAS; Nánjīng Hydraulic } \\
\text { Research Institute }\end{array}$ & $\mathrm{AD}$ & FG (6) & Běijīng & 10.06 .2011 \\
\hline $\begin{array}{l}\text { NGO } \\
\text { W1 }\end{array}$ & M & Green Watershed & NGOW & II & Běijīng & 08.06.2011 \\
\hline $\begin{array}{l}\text { NGO } \\
\text { W2 }\end{array}$ & M & $\begin{array}{l}\text { World Agroforestry Centre (also } \\
\text { Kūnmíng Institute of Botany, } \\
\text { Chinese Academy of Science) }\end{array}$ & NGOW & II & $\begin{array}{l}\text { Kūnmíng, } \\
\text { Yúnnán }\end{array}$ & 13.06 .2011 \\
\hline $\begin{array}{l}\text { NGO } \\
\text { W- } \\
\text { FG }\end{array}$ & $\mathrm{F}$ & $\begin{array}{l}\text { Yúnnán EcoNet; } \\
\text { Green Watershed }\end{array}$ & NGOW & FG (4) & $\begin{array}{l}\text { Kūnmíng, } \\
\text { Yúnnán }\end{array}$ & 14.06 .2011 \\
\hline $\begin{array}{l}\text { NGO } \\
\text { W3 }\end{array}$ & M & $\begin{array}{l}\text { Institute for Sustainable } \\
\text { Communities }\end{array}$ & NGOW & II & $\begin{array}{l}\text { Guăngzhōu, } \\
\text { Guăngdōng }\end{array}$ & 15.06 .2011 \\
\hline $\begin{array}{l}\text { NGO } \\
\text { W4 }\end{array}$ & M & $\begin{array}{l}\text { Earth Journalism Network, } \\
\text { Internews China }\end{array}$ & NGOW & II & $\begin{array}{l}\text { Guăngzhōu, } \\
\text { Guăngdōng }\end{array}$ & 15.06 .2011 \\
\hline $\begin{array}{l}\text { NGO } \\
\text { W5 }\end{array}$ & $\mathrm{F}$ & Greenovate & NGOW & II & Shànghăi & 10.01 .2013 \\
\hline
\end{tabular}




\begin{tabular}{|l|l|l|l|l|l|l|}
\hline $\begin{array}{l}\text { NGO } \\
\text { W6 }\end{array}$ & F & Green City & NGOW & II & Shànghăi & 15.01 .2013 \\
\hline GP1 & M & $\begin{array}{l}\text { Gāolígòngshān Farmers' Biodiver- } \\
\text { sity and Conservation Association }\end{array}$ & GP & II & $\begin{array}{l}\text { Băihuālǐng } \\
\text { Gāolígòngshān, } \\
\text { Yúnnán }\end{array}$ & 11.06 .2011 \\
\hline
\end{tabular}

\section{Keys}

GO Government Official

II Individual Interview

MP Media Professional FG Focus Group

AD Academic FG (n) number of participants in FG

NGOW NGO Worker

GP General Public 